\title{
Sacrifice, Guilt, and Dreams in a Woman's Life: Ashima in the Namesake and Suyuan in the Joy Luck Club as Examples
}

\author{
Reem Nasser Al-Aulaqi \\ Phd Student at Al-Neelain University, Khartum, Sudan. \\ Dr. Eiman Abbass El-Nour \\ Associate Professor at Al-Neelain University, khartum, Sudan.
}

\begin{abstract}
The Namesake by Jhumpa Lahiri and The Joy Luck Club by Amy Tan are two great novels which in addition to their focus on the concept of migration and its impacts on the lives of migrants in general and on female migrants in specific they also deal with another concept of great importance which is the meaning of sacrifice, guilt, hopes and dreams in the life of a female migrant. Ashima is an example of women who leave their education, career and jobs, give up their dreams and sacrifice everything to be "good wives" and raise children. In The Namesake, Ashima sacrificed everything she loved in India in order to join her husband who moved to America to fulfil his own dream of studying abroad. Her decision to marry Ashoke and migrate with him was a life- changing sacrifice because she had to leave her dreams behind in favour of taking her responsibilities and obligations as a wife. America was never her dream and therefore she never felt at home there but she had to stay there as long as her husband desired. Then as soon as Ashoke died she left everything in America and went back to India to fulfil her dreams which she had once ignored in favour of her husband's dreams.
\end{abstract}

Keywords: Women, Family, Children, Dream, Pursue, Fulfil, Sacrifice, Migration, Hope, Separation, Guilt , Fear, East, America, Joy, Pain

For being a foreigner, Ashima is beginning to realize, is a sort of lifelong pregnancy - a perpetual wait, a constant burden, a continuous feeling out of sorts. It is an ongoing responsibility, a parenthesis in what had once been ordinary life, only to discover that that previous life has vanished, replaced by something more complicated and demanding. Like pregnancy, being a foreigner, Ashima believes, is something that elicits the same curiosity from strangers, the same combination of pity and respect (Jhumpa Lahiri 49).

On the other hand, Suyuan in The Joy Luck Club had no other option but to migrate to America because of the deteriorating situation and the war in China. During the war in China, she had lost her twin babies but she had never forgot them or gave up the hope of reuniting with them in spite of the fact that the chance of finding them was so rare especially after many years of separation. She tried her best to never relinquish hope throughout her life in spite of the obstacles. When she died, her friends described her death as that of a rabbit in that she was full of life and her death was all of a sudden as she was supposed to host the next meeting of her club; the Joy Luck Club. The irony was that her dream of finding her twin daughters was not fulfilled during her lifetime but rather after her death although she had lived all her life with the hope of making that dream come true. Suyuan's death may have something to do with her "long-cherished wish" as well; the wish she had never lost hope to fulfil. That was what the ladies of the Joy Luck Club were pointing at the opening of the novel when they said that Suyuan died "with unfinished business left behind" - she had not yet found her twin daughters. Suyuan's dream was then fulfilled by her American born daughter June who went after her mother's death to China to meet her twin sisters and fulfil her mother's dream. Ashima and Suyuan migrated to America; the so called land of dreams but the irony was that the land of dreams and opportunities had nothing to offer Ashima and Suyuan whose dreams were finally fulfilled back home and not in America. Suyuan like the other the ladies of The Joy Luck Club, considered migrating to America as an opportunity to have a prosperous quiet life for them and their children. A life in which they can dream of the future with no fear of facing the complications and problems they have faced in their homeland. They migrated carrying their own dreams not with the intention to achieve the American dream. They migrated carrying lots of dreams and raising high expectations for 
their children and themselves. "America was where all my mother's hopes lay. She had come here in 1949 after losing everything in China: her mother and father, her family home, her first husband, and two daughters, twin baby girls. But she never looked back with regret. There were so many ways for things to get better" (Amy Tan 132).

\section{TheORETICAL FraMeWORK}

Any study that emphases on women must go through the leading theories on women. Accordingly and as the core of this article is women and especially women migrants, it became essential to relate to the theories that concentrated on both migration and women. In connection to this, Monica Boyd and Elizabeth Grieco (2003) in their study titled (Women and Migration: Incorporating Gender into International Migration Theory) presented the connection between the theories on feminism and the theories of international migration. They believe that understanding women is critical in the overall understanding of the causes behind women migration or the effects of migration on women. In that they wrote:

Over the last 25 years, there has been little concerted effort to incorporate gender into theories of international migration. Yet, understanding gender is critical in the migration context. In part because migration theory has traditionally emphasized the causes of international migration over questions of who migrates, it has often failed to adequately address gender-specific migration experiences. Without clear theoretical underpinnings, it becomes difficult to explain, for example, the conditions under which women migrate, or the predominance of women in certain labor flows and not in others.

C. Llewellyn (2012) emphasized on the importance of the studies on gender and migration and the relationship between the two. The following was part of her article in that:

The relationship between gender and migration is a hot topic in the social sciences and humanities. Increasingly, more books and articles, as well as conferences and working groups of scholars, tackle how gender intersects with migratory processes.... The rise of this type of work can be attributed to the acknowledgement of feminist theory in mainstream social sciences and humanities. In terms of this particular field, scholars recognized that works on migration had a masculine bias; the research overlooked women's experiences. In response, we have seen a proliferation of works that address both male and female (though mostly female) migrants and the gendered components of their movements.

C. Llewellyn(2012) then related to a study by Stephaine Nawyn which explained the need for more focused studies that would help in a better understanding of the real reasons behind the migration of women. In her study, Nawyn pointed out that feminist theory is missing or undervalued in sociology. Stephanie Nawyn, in her 2010 Sociology Compass article (Gender and Migration: Integrating Feminist Theory into Migration Studies), explains that mainstream sociological migration studies has not fully acknowledged a feminist theoretical perspective. Most works from the mainstream describe the economic motivations and push/pull factors of migration; these are topics that surely have a gendered component, but few works adequately incorporate gender into their analyses. In fact, Nawn explains that we still know very little about why people migrate (theories of migration) and how migrants improve their social statuses (theories of assimilation) from a feminist perspective.

Judith Stacey and Barrie Thorne. (1985) pointed to the same idea of Nawyn, but the difference was Nawyn's suggestions for future directions. C. Llewellyn(2012) explains Nawyn's suggestions as:

Nawyn would like to see researchers take a feminist approach when designing their studies. For example, a feminist perspective predicts that the presence of children will have different impacts on men's and women's migration experiences. Since childrearing is a gendered phenomenon, men and women will have different responsibilities and roles with regard to their children, and thus men and women will have different earnings in the migration process. A feminist perspective would allow researchers to choose appropriate variables and ask the right questions when investigating gender and migration.

On the other hand, scholars like Aina Tollefsen Altamirano (1997) in her research titled (Feminist Theories and Migration Research-Making Sense in the Data Feast?) researched some recent developments within feminist geography and tried to find answers to the questions of whether feminist theories can contribute to the understanding of international migration. In her abstract, she wrote: 
The conclusion is that migration research can benefit from feminist empiricism through detailed documentation and measurement of gendered migration streams, while the essentialism of antirationalist feminism could lead to over-generalizations in terms of male and female mobility. Post-rational feminist approaches to migration research could contribute to studies of subgroups of migrants (both women and men) and their relational position in different contexts.

\section{SACRIFICE; A SYNONYM FOR WOMEN}

Sacrifice is the synonym of Woman or Woman is the synonym of Sacrifice......Oh...one of my classmate is leaving...because her husband doesn't want her to study further...she left so that she can avoid all those fights, which were happening since day one she joined the college... and to save her child's future who is only $11 \ldots$ now she want to save her marriage for her child's future...not because she loves her husband...

https:/thafreebird.wordpress.com/2014/08/19/a-womans-life-is-all-about-sacrifice/

Late in the sixties, Ashima Ganguli, a nineteen year old Bengali woman arrived at Cambridge, Massachusetts with her new husband Ashoke. Just after they got married, she had to migrate to America with her husband who wanted to fulfil his own dream of studying abroad. She had never known or loved Ashoke before their marriage to sacrifice everything for him but in spite of that she willingly left everything she loved in India in order to move with her husband just as it is expected from women in many cultures around the world to be the submissive, obedient and sacrificing pole in the family."She was nineteen, in the middle of her studies, in no rush to be a bride. And so, obediently but without expectation, she had untangled and rebraided her hair, wiped away the kohl that had smudged below her eyes" (Jhumpa Lahiri 7).

It is certain that a family is the most important unit of a society and therefore it is always conventional to have different kinds of compromises to keep the unity of it. But although creating a prosperous family is the responsibility of men and women alike it is mostly assumed that women are the ones to sacrifice whenever the family needs support and assistance. Ashima like many women around the world was not forced to sacrifice but she did it readily just as part of her nature as a woman. To many women, family comes first whenever there is need for compromise and that is the reason behind Ashima's compromise between her love to music and piano lessons and her duties as a wife. "I feel most women do not love themselves enough and sacrifice too much of themselves for men (husbands, lovers, boyfriends, and at times even their own fathers) as well as for their own children and extended families (parents, siblings, in-laws)."

http://nehandaradio.com/2012/01/20/women-sacrifice-too-much-for-men/

Ashima left her homeland, parents and relatives, her dreams and hobbies in order to join her husband. Marrying a well-educated man and travelling to America was a golden chance that Ashima the young Bengali women would not like to lose. "Ashima had never heard of Boston, or of fiber optics. She was asked whether she was willing to fly on a plane and then if she was capable of living in a city characterized by severe, snowy winters, alone. "Won't he be there?" she'd asked, pointing to the man whose shoes she'd briefly occupied, but who had yet to say a word to her" ( Jhumpa Lahiri 9).

Suyuan in the Joy Luck Club had to sacrifice too; her sacrifice had its influence on her entire life from that time on. During the war in China, she had to leave her twin babies by the side of the road with all the valuables she had so that whoever finds them can take well care of them. She sacrificed everything to protect her daughters, while ignoring her own fatal illness to get them far away from the enemies. She was so desperately sick, unguarded, lonely and insecure and she did not want to die with her twin babies in her arms. When she felt like dying she did not want to die between her babies because to her that would mean that her ghost will follow her twin babies with bad luck throughout their lives. The irony was that she did not die but was then saved and taken to the hospital just after she had left her babies by the side of the road. From that time on, Suyuan's only dream was to find her babies again and overcome the feeling of guilt she deeply felt since she had lost them. When she migrated to America, she had no dreams for herself. All she dreamed of was a better life for her daughter June; a life full of hope, good luck, happiness and safety. "Your mother was a very strong woman, a good mother. She loved you very much, more than her own life. And that's why you can understand why a mother like this could never forget her other daughters. She knew they were alive, and before she died she wanted to find her daughters in China" (Amy Tan 39). 


\section{The Land Of Dreams Had No Dreams FOR ASHIMA AND SUYUaN}

"America was where all my mother's hopes lay. She had come here in 1949 after losing everything in China: her mother and father, her family home, her first husband, and two daughters, twin baby girls. But she never looked back with regret. There were so many ways for things to get better" (Amy Tan 132). To many Chinese, America was thought of as the land of dreams coming true. Suyuan migrated with hopes of a better leaving behind all her sorrows and miserable memories. In America, Suyuan made a new family together with her husband Canning, learned English well enough, raised her new daughter; June, and even ended up owning her own apartment complex. Suyuan showed that she was not the kind of person to sit back and let life happen to her; she was a self-starter who was active in seeking out her own happiness and was determined to live life to the fullest no matter what circumstances would surround her.

Suyuan strongly believed in the American Dream; that people can come to America and become rich and famous or whatever they want to be, so long as they try. Her notion of America was in line with her own values - Suyuan believed in actively reaching for her own happiness. "My mother believed you could be anything you want to be in America. You could open a restaurant. You could work for the government and get good retirement. You could buy a house with almost no money down. You could become rich. You could become instantly famous" (Amy Tan 132).

On the contrary, America was never Ashima's dream and throughout her stay there she had always felt like a stranger. She was there only because her husband had his dreams there but for her everything she loved was back in India. She felt so alone and isolated and would cry over little things which would remind her of her homeland. When she gave birth to her first son, Ashima mourned the fact that she is not surrounded with her parents and relatives in such a special occasion. She thought of going back to India to raise her children there but her husband refused because he felt that America had best opportunities and chances for their children.

For as grateful as she feels for the company... these acquaintances are only substitutes for the people who really ought to be surrounding them. Without a single grandparent or parent or uncle or aunt at her side, the baby's birth, like most everything else in America, feels somehow haphazard, only half true. As she strokes and suckles and studies her son, she can't help but pity him. She has never known of a person entering the world so alone, so deprived. (Jhumpa Lahiri 24)

Although Ashima's husband was so loving, caring and supportive, that did not help Ashima overcome her continuous longing to India and to all the beautiful memories she missed there. This nostalgia kept her from achieving any accomplishments on the personal level and during the course of her long years in America Ashima dedicated her life to her husband and kids who where her everything and she had no thoughts for her own desires and needs. She had to endure long hours of being alone at home when Ashoke was away for his work. Ashima had always felt so cold and lonely just as cold as the weather around her since her arrival in America. "He looks at Ashima, her face leaner, the features sharper than they had been at their wedding, aware that her life in Cambridge, as his wife, has already taken a toll. On more than one occasion he has come home from university to find her morose, in bed, rereading her parents' letters" (Jhumpa Lahiri 33).

\section{IT IS EITHER SACRIFICE OR GUILT}

Ashima and Suyuan are two examples of devoting personalities who had sacrificed willingly and who on the other hand tend to feel guilty and uncomfortable whenever they do not live up to the supposed expectations of their families. Suyuan's feeling of guilt after losing her twin babies had its impact on her relationship with her American born daughter; June. Although Suyuan had sacrificed her life to save her twin babies but the feeling of guilt that she could not keep them and had instead lost contact with them had caused a great sorrow in her heart. Thus and in order to conquer her inner feeling of guilt of her failure to save her twin babies at the past, she had tried her best to keep June happy and safe. Her excessive intervening in the life and choices of her daughter led to a weak shaky personality on behalf of her daughter. Suyuan feared that her daughter would be a copy of her and that she would not be able to make good choices and would commit mistakes that would cause her to suffer throughout her life which is something any mother would not wish it to happen to her daughter. She did not want her daughter to feel the guilt she herself was feeling because of her bad choices and mistakes and that was the reason that Suyuan never elaborated to June the painful story of losing the 
twins as an attempt to protect her daughter from the feelings of sorrow and sadness by keeping it to herself. This has just widened the communication gap between the mother and her daughter which usually takes place between many migrated parents and their children due to different reasons. "I had always assumed we had an unspoken understanding about these things:that she didn't really mean I was a failure,and I really meant I would try to respect her opinions more......My mother and I never really understood one another" (Amy Tan 37).

Suyuan's over protection to June and her lack of trust in June's abilities and skills ruined June's life and personality. Though Suyuan had acted that way out of love and as a reaction to her failure as a mother in the past but the way in which she was dealing with June was never positive or nurturing to the soul or mind of her daughter.

And then it occurs to me. They are frightened. In me, they see their own daughters, just as ignorant, just as unmindful of all the truths and hopes they have brought to America. They see daughters who grow impatient when their mothers talk in Chinese, who think they are stupid when they explain things in fractured English. They see that joy and luck do not mean the same to their daughters, that to these closed American-born minds "joy luck" is not a word, it does not exist. They see daughters who will bear grandchildren born without any connecting hope passed from generation to generation. (Amy Tan 40)

Suyuan's could not overcome her feelings of guilt thus her life was a combination of sacrifice, guilt, a continuous search for a kind of self-satisfaction, and a never failing attempt to beautify her image as a mother through trying to be a successful mother to June and trying her best to fulfil her one and only dream of reuniting with her twins once again in her lifetime. The feelings of guilt that they might be negligent, selfish and uncaring that many mothers around the world feel at certain stages of their lives can to some extent be considered as normal feelings which might in times turn into something more serious when those mothers fail to overcome their feelings of guilt and can never live a normal life. That was the case of Suyuan who could not live normally after she had lost her babies because of her deep boundless feeling of pain and sorrow and her additional suffering due to her inability to share her pain with people around her. Suyuan had secretly searched for her lost babies for forty years, exposing the extent of her devotion as a mother and the level of sacrifice towards June by not sharing the pain with her in order to protect her from any kind of emotional pain that she might feel after discovering her mother's suffering. On the other hand, she tried constantly to convince June that her migration to America was because she carried good intentions to start a new life full of hope, love and better opportunities for her and her new family. "On her journey she cooed to the swan: "In America I will have a daughter just like me. But over there nobody will say her worth is measured by the loudness of her husband's belch. Over there nobody will look down on her, because I will make her speak only perfect American English" (Amy Tan 17).

After the death of Suyuan, June came to realize that the story she thought was a fairy tale was actually a real event in her mother's life. As she learned more about her mother's past and life in China she came to respect her mother more. The more she understood her mother's life and sacrifices the more it gave her strength and courage to face life obstacles. As June faced some life trials of her own, she recognized that her mother felt the same during her life and that her mother's life was never easy or smooth. Suyuan's voice would echo in June's head reminding her of the hard times her mother had to live and to what extent she tried her best to remain strong and steadfast."Can you imagine how it is, to want to be neither inside nor outside, to want to be nowhere and disappear? "(Amy Tan 22)

Ashima also felt guilty when her husband died without her being next to him although she had always been there for him. She felt painful that she had refused to accompany him when he had to move to another state because of his work and she had rather preferred to stay home with her kids. As a mother, Ashima had to choose between moving with her husband or staying with her son and daughter. Since she had moved to America, her entire life was centred on her family and their needs and she had neither time nor intention to think about herself or her own desires. Therefore, Ashoke's death with her not next to him was so painful for her and caused her feelings of guilt, distress and agony. 


\section{The Expensive Price}

Devoting women like Ashima and Suyuan who usually devote their entire lives to people around them are examples of women who find strength and comfort in serving others but the real tragedy is that when those women themselves suffer, they find themselves so lonely and isolated with no one to ease their sufferings. When Ashima's husband died, she felt so lonely and scared and there was no one next to her with whom she can share her pain. It is because those women never felt like seeking help from others or even sharing their feelings with people around them. They always wanted to protect their loved ones and so they never shared their pain or sorrow with them. Ashima although never felt happy in America, she never shared her feelings with her family and would instead cry quietly for hours without seeking help from them. "Early mornings, when he senses that she is quietly crying, he puts an arm around her but can think of nothing to say, feeling that it is his fault, for marrying her, for bringing her here" (Jhumpa Lahiri 33).

The same thing happened with June in The Luck Club who never knew of her mother's suffering till after her mother died. Her ignorance made her feel guilty that she did not value her mother enough during her life. "I never thought my mother's Kweilin story was anything but a Chinese fairy tale" (Amy Tan 25).

The failure of the people around those women to appreciate their suffering and sacrifice adds to their distress and agony especially when their loved ones never understand or value that kind of sacrifice. When Ashoke died, Ashima felt so tortured because her son and daughter were not next to her when their father died although it was because of them that Ashima had left her husband alone during his last days. She felt so painful that they did not appreciate her sacrifice and at the same time so guilty that she was not there next to her husband when he passed away. "She feels a wave of sympathy for him, at the thought of him driving to the hospital alone. She misses him suddenly, remembering afternoons years ago when they'd first moved to this town, when he would surprise her and come home from university in the middle of the day" (Jhumpa Lahiri 164).

It was all of a sudden that Ashima found herself all alone and lost. Ashoke was Ashima's everything in America. Her life was dedicated to him and her children and when he died she felt as if life had suddenly stopped.

Ashima feels lonely suddenly, horribly, permanently alone, and briefly, turned away from the mirror, she sobs for her husband. She feels overwhelmed by the thought of the move she is about to make, to the city that was once home and is now in its own way foreign. She feels both impatience and indifference for all the days she still must live, for something tells her she will not go quickly as her husband did. (Jhumpa Lahiri 278)

Just as Ashoke's marriage to Ashima changed her life, his death also was another turning point in Ashima's life. After his death, she started to think of her life differently. She realized that she should have learned how to be independent and have her own life. When she decided to go back to India after her husband died, she just then realized that there was nothing for her in America to stay for. All the years she has spent in America were like a dream. She was convinced that her children who wanted to merge wholly in the American life and who seem not to care for their mother who had dedicated her whole life to them will just be fine without her being around and that it was just about time for her to go pursue her own dreams.

And then the house will be occupied by strangers, and there will be no trace that they were ever there, no house to enter, no name in the telephone directory. Nothing to signify the years his family has lived here, no evidence of the effort, the achievement it had been. It's hard to believe that his mother is really going, that for months she will be so far. He wonders how his parents had done it, leaving their respective families behind, seeing them so seldom, dwelling unconnected, in a perpetual state of expectation, of longing. (Jhumpa Lahiri 281)

Ashima was convinced that it is time for her to take a step back, go deep into her inner self and listen to her soul in order to find the true Ashima which she had lost years ago. Therefore, she believed she should never surrender to the feelings of loss and weakness but on the contrary try to draw happiness and strength from within herself by recalling the things she once used to love in India before migrating to America. 
For thirty-three years, she missed her life in India. Now she will miss her job at the library, the women with whom she's worked. She will miss throwing parties... She will miss the country in which she had grown to know and love her husband. Though his ashes have been scattered in the Ganges, it is here, in this house and in this town that he will continue to dwell in her mind. (Jhumpa Lahiri 279)

\section{WOMEN BETWEEN DREAMS AND REALITY}

Many women tend to have dreams and longings at certain points of their lives, but over time, they lose touch with those dreams and desires. Over the years, those dreams and aspirations seem more like illusions or hard to fulfil dreams. Many women feel as if they were being trapped within their circumstances and that life had many obstacles that made them think of happiness as being settling, or making the best of what they already have without excessive imagination. Sometimes they get this understanding implied in a message at a very young age from people around them and sometimes from their own mothers who use to fill their minds with the idea of clinging to what is already in hand rather than dreaming of more as if dreaming will cause them to lose everything.

Stuck in the middle of their struggles in a male-dominated society, sinking in their home and family responsibilities, and failing to get over their emotional and career disappointments, women find themselves faintly murmuring that it seems much wiser to be satisfied with what is in front of them, rather than undergoing a perplexing full of difficulties journey toward their dreams. Doing so, made it easier for those women to manage their lives within the concrete or hypothetical boundaries of the societies they live in and even find a sense of protection and security in the middle of all this. They look for settling and safety although it can mean being in the middle of an unhealthy relationship with partners whom they never loved or respected. In many times, they suppress their feelings of being emotionally unsatisfied; their inability to feel the warmth of their souls, their shivering whenever they think of how their lives could have changed if they fulfilled their dreams.

Suyuan in The Joy Luck Club is an example of women who try to find joy in the middle of misery. She is not the kind of person to sit back and let life happen to her; she is instead an achiever who is active in seeking out her own happiness and is determined to live life to the fullest no matter what hard the circumstances and obstacles that would surround her. "And each week, we could hope to be lucky. That hope was our only joy. And that's how we came to call our little parties Joy Luck." (Amy Tan 25).

The intention of Suyuan when she started the club of women which she named the Joy Luck Club was to bring together a community of women to rejoice their happiness and luck in life despite the suffering and obstacles they are facing. Suyuan wanted to teach the women in the Joy Luck Club that they should live their lives in spite of all their problems. To show them that happiness sometimes lays in the small details, that life never stops no matter what obstacles they face, and that it is in their own hands to choose to be happy or not. What really hurts the most is that in spite of those women's continuous struggle to cheat themselves at the first place and then the people around them of how happy and satisfied they really are, there is that deep feeling that they could not ever get rid of which keeps them to the thought that there has got to be more than this. Although this feeling of longing to what is better is mostly being suppressed whenever women find settling and safety, it is like a tremendous force that strongly shakes the rock of settling just as it comes to the surface. Thus leaving women feeling so empty, shivery and plain tired, but still unable to make the first move towards the change because of the dominant feeling of fear. Fear of the unknown, fear of failure, fear of incapability, fear of criticism, and fear of losing what is already in hand. The reluctance to face any of those fears is often what leaves women stuck in their places with feelings of boredom and dissatisfaction rather than experiencing a sense of satisfaction and success.

The Joy Luck Club mainly focuses on the expectations, hopes, and dreams that those women and their daughters have for themselves. Amy Tan and through the Characters of The Joy Luck Club shows the hardships each mother experiences as a child and then as a young adult, and how on return all those women wished for better lives for their daughters. The lives of the mothers were full of complications but they tried to face all that with hope. People thought those women were with no problems and that they were carless and evil because they would gather to eat, play and laugh and seem not to feel the miseries of others. They believed that those women must have been possessed with demons to be able to celebrate while others lose their homes, fortunes and their loved ones. To Suyuan, the picture was 
not as it was seen by the blamers. To her, life was also so miserable but she would choose to live with hope rather than to look back and cry on her bad luck.

Suyuan was the kind of woman who would think positively and find a way even in the most miserable situations. When she reached the moment that she had to lose everything including her twin babies. She left her babies by a tree with a letter promising more money if those babies were brought to their father in Chungking. She left them there when she had no hope of surviving her own life. Her good intentions made her think that by doing so she can promise those babies a safe life rather than dying with her babies between her arms.

By losing her twin babies, Suayan had lost everything except her ties to China. The three fancy silk dresses which she was wearing one on the other throughout her journey were like a symbol that Suayan will still have ties to China and that the story will never end here as she thought. "I thought I had lost everything, except these two things, she murmured. "And I wondered which I would lose next. Clothes or hope? Hope or clothes?" (Amy Tan 283)

The thought that she might have died in China was not the end of the story but rather it was the beginning of another story that Suayan did not expect to happen. "What do you mean by everything?" I gasped at the end. I was stunned to realize the story had been true all along. "What happened to the babies?" She didn't even pause to think. She simply said in a way that made it clear there was no more to the story..." (Amy Tan 26).

The new life that Suyuan was given after she lost her babies was the driving force that gave her hope she can find her babies again one day. Suayan's dream of re-joining her baby twins was the bond that connected her to the East. This connection was described by the following quote by her daughter June, "It's her place on the table, without having anyone tell me, I know her corner on the table was the East. The East is where things begin, my mother once told me, the direction from which the sun rises, where the wind comes from" (Amy Tan 33).

To be the place from which the sun rises as well as being the place from which the wind comes, was how Suayan feels about the East. To her the East was the source of happiness and sorrow at the same time. It was where she learned how to hope but also where she lost that hope. It was the place where she experienced the beauty of being a mom for the first time but also where she felt the pain of losing her children. It was where she experienced the splendour of having hope during her gatherings with her friends in the Joy Luck club but then experienced the sorrow of being forced to leave her country because of war and unsafety. The bad luck Suyuan was trying to save her babies from by leaving them by the side of the road tracked her as she was not dead as she expected. Suyuan did not die in China, but instead she lost her entire family.

\section{The PHOPIA OF FAILURE}

The first move toward making the positive change and removing oneself from an unfulfilling condition is never a sudden all at once step. It is a combination of positive thoughts, courage, selfconfidence, and a strong forward action on the right path. The fear of not finding that right path might stop one from taking the first step, on the other hand sometimes even when the path is already identified women still fear to take the first step and would rather quit before giving a try.

There is a kind of inner scolding voice that keeps reminding women that they are not capable of taking the first step towards their dreams at certain points of their lives and this feeling of self-doubt affects their relationship with their own children. This voice of self-judgment keeps echoing negatively that there is nothing right in their lives and in that happy, successful and inspiring lives are not meant for them. Thus, and as a reaction, those women try their best to make a better life for their own children but unfortunately their past keeps influencing them in a way that ruins their children's lives instead of flourishing it. Instead of giving their children the chance to choose their path and their future, they yet filled with good intentions draw a picture of that future and force their children to paint it without taking into consideration those children's own dreams and desires. "And after seeing my mother's disappointed face once again, something inside of me began to die. I hated the tests, the raised hopes and the failed expectations" (Amy Tan 134).

Those women's fear that their children might commit the mistakes of not choosing right dominate the way those women deal with their children throughout their lives. Their miserable memories of their past, their failure to achieve their own desires, their unsatisfied relationships with their partners and 
careers influence the way they guide their children. And instead of serving as a source of positive advice, assistance and guidance to their children they unintentionally become the source of discouragement and annoyance. And that was exactly the case with Suyuan and Ashima's relationship with their children. They were neither able to meet each other's expectations nor fulfil their own dreams. That was it. They had different expectations, different abilities and different dreams. "I think about this. My mother's long-cherished wish. Me, the younger sister who was supposed to be the essence of the others. I feed myself with the old grief, wondering how disappointed my mother must have been" (Amy Tan 281).

\section{REFERENCES}

Altamirano, Aina Tollefsen "Feminist Theories and Migration Research-Making Sense in the Data Feast?" Refuge, October 1997, Vol. 16, No. 4.

Boyd, M. 1986. "Immigrant Women in Canada." In International Migration: The Female Experience, eds. R. Simon and C. Brettell. Totowa, New Jersey: Rowman and Allanheld.

1989. "Family and Personal Networks in International Migration: Recent Developments and New Agendas." International Migration Review 23: 638-671.

1992. "Gender Issues in Immigration and Language Fluency." In Immigration, Language, and Ethnicity, ed. B. Chiswick. Washington, D.C.: AEI Press.

Boyd, M, \& Grieco, E, 2003. "Women and Migration: Incorporating Gender into International Migration Theory" Migration Information Source, Washington, MPI.

Butler, Juidth 1990. Gender Trouble: Feminist and Subversion of Identity, New York and London: Routledge

Gabaccia, Donna 1992. From the Other Side: Women, Gender and Immigrant Life in the U.S., 1820-1990, Bloomington: Indiana University Press.

Grieco, E.M. and M. Boyd. 1998. "Women and Migration: Incorporating Gender into International Migration Theory." Center for the Study of Population, Florida State University, Working Paper 98-139.

Lahiri, Jhumpa 2003. The Namesake, New York: Houghton Mifflin Company.

Llewellyn, C. 2012. "Feminism and Migration Studies" Sociology Lens. http://www.unescap.org/sdd/ issues/migration/migration.asp

Nawyn, S. J. (2010). "Gender and Migration: Integrating Feminist Theory into Migration Studies" Sociology Compass, Vol.4: pp. 749-765.

Stacey, J, \& Thorne, B, 1998. "The Missing Feminist Revolution in Sociology" Social Problems Vol. 32, No. 4 .University of California Press, pp. 301-316.

Tan, Amy 2006. The Joy Luck Club, New York: Penguin Group.

https://www.quora.com/Why-do-women-sacrifice-their-career-for-procreation

http://nehandaradio.com/2012/01/20/women-sacrifice-too-much-for-men/

http://hubpages.com/family/forum/17349/do-women-sacrifice-more

https://thafreebird.wordpress.com/2014/08/19/a-womans-life-is-all-about-sacrifice/

http://www.nairaland.com/1499046/should-woman-sacrifice-dreams-marriage

https://answers.yahoo.com/question/index?qid=20140122114550AAn2cly

\section{AUTHORS' BIOGRAPHY}

Reem Nasser Abdullah Al-Aulaqi, is a demonstrator in the Department of English and Faculty of Arts and Humanities at University of Sana'a, Yemen. She is currently a PhD student at Al-Nileen University, Khartum, Sudan. She completed her master degree in Master of Arts, English Literature at University of Sana'a, Sana'a, Yemen. (July_2009) based on the Thesis: Satire and Irony in Animal Farm: A Critical Study. She completed her bachelor degree in Bachelor of Arts, English Literature at University of Sana'a, Sana'a, Yemen (June_2000) and finished high school at Azal Modern School, Sana'a, Yemen (June_1993).

Eiman El-Nour, is associate professor in English Literature ar Neelain University and Ahfad University, and teaching fellow at Khartum University. She is also fellow of Wolfson College, Cambridge. She specialises in teaching African Literature and her main research themes include African women's writing. Sudanese Literature and Sudanese orality. She is author of Hadha Huwa alMakan!: Fi Tadhakkur al-Tayyib Salih ( This is the place!:Remembering Tayeb Salih) (2010) 